\title{
PENGARUH PENGGUNAAN JENIS SUMBER GULA DAN UREA TERHADAP HASIL FERMENTASI NATA DE PINA
}

\author{
Bima Rizkia Ramadhan ${ }^{1}$, Maya Ellisa Rangkuti ${ }^{1}$, Silvia Inge Safitri ${ }^{1}$, Veraditias Apriani ${ }^{1}$, Angsari Sitorani \\ Raharjo $^{1}$, Ednita Androgini Titisgati ${ }^{1}$, Diana Nur Afifah ${ }^{2 *}$ \\ ${ }^{1}$ Pusat Pelayanan Kuliah Kerja Nyata (P2KKN), Lembaga Penelitian Dan Pengabdian Kepada Masyarakat \\ (LPPM) Universitas Diponegoro \\ ${ }^{2}$ Departemen Ilmu Gizi, Fakultas Kedokteran, Universitas Diponegoro \\ ${ }^{*}$ Corresponding author: d.nurafifah.dna@fk.undip.ac.id
}

\begin{abstract}
Background : pineapple is a fruit plant from Brazil. Processing of pineapple in Indonesia is still traditional and has a low selling value. So, making nata from pineapple will be more profitable. Nata products derived from pineapple are known as Nata de Pina. The largest content of nata is water (98\%) so that nata is a low calorie food. Nata is formed by acetic acid bacteria on the surface of a liquid containing sugar/fruit juice or other plant extracts. Bacteria that are grown in the processing of nata namely Acetobacter Xylinum.

Objectives : the aims of this study was to find out how to make good nata by using honey pineapple as a ingredients, to observe the processed results qualitatively and to analyze the characteristics of nata by proximate test

Methods : The initial stage of making nata was the selecting of pineapple, washing pineapple and tools to be sterile from contaminants, preparing pineapple, adding sugar and adding urea $10 \mathrm{~g} / 5 \mathrm{l}$ ingredients. Then, boiling the ingredients, adding vinegar, placing the ingredients into the container, adding bacteria, and fermenting the ingredients for 14 days. Results : The results og the study was showed that the addition of urea and the use of sugar gave the best results, the best colour white with thickness of 10,2 mm, water content of $5.17 \%$, ash content of $0.75 \%$, fat content of $1.2 \%$, insoluble fiber $2.29 \%$ and protein of $10.88 \%$ in $100 \mathrm{~g}$ dry ingredients.

Conclusion: The best results of the nata de pina is by adding urea and sugar. This study is expected to be able to provide information on how to process honey pineapple into good Nata.
\end{abstract}

Keywords : fermentation, nata de pina, Acetobacter Xylinum, urea, type of sugar.

\begin{abstract}
ABSTRAK
Latar belakang : Nanas (Ananas comosus) merupakan tanaman buah yang berasal dari Brazil. Pengolahan nanas di Indonesia yang masih tradisional dan memiliki nilai jual yang rendah menyebabkan diolah menjadi nata lebih menguntungkan. Produk nata yang berasal dari nanas dikenal dengan Nata de Pina. Kandungan nata terbesar adalah air (98\%) sehingga nata merupakan sumber makanan rendah kalori. Nata dibentuk oleh bakteri asam asetat pada permukaan cairan (medium) yang mengandung gula / sari buah/ ekstrak tanaman lainnya. Bakteri yang ditumbuhkan dalam pembuatan nata yaitu Acetobacter Xylinum.

Tujuan : Tujuan dari penelitian Nata de Pina adalah untuk mengetahui cara pembuatan nata yang baik dengan memanfaatkan nanas madu sebagai bahan baku, untuk mengamati nata hasil olahan secara kualitatif, menganalisa karakteristik nata yang terbentuk dengan pengujian proksimat.

Metode : Tahapan awal pembuatan nata adalah pemilihan buah nanas, pencucian bahan dan alat agar steril dari kontaminan, penyiapan bahan baku, penambahan gula (gula pasir, gula Tropicana slim), penambahan urea 10 gr/ $5 l$ bahan. Selanjutnya dilakukan pendidihan bahan baku, penambahan cuka, penempatan bahan ke dalam wadah, penambahan bakteri Acetobacter xylinum, melakukan fermentasi terhadap bahan selama 14 hari dan pemanenan.

Hasil ; Hasil uji didapat penambahan urea dan penggunaan gula memberikan hasil yang terbaik yaitu tebal 10,2 mm dengan warna putih paling baik, kadar air sebanyak 5,17\%, kadar abu 0,75\%, lemak 1,2\%, serat kasar 2,29\%, dan protein kasar 10,88\% dalam 100\% bahan kering.

Kesimpulan : pembuatan nata de pina dengan hasil terbaik adalah dengan penambahan urea dan penggunaan gula. Penelitian ini diharapkan mampu memberikan informasi cara pengolahan nanas madu menjadi nata de pina yang baik.
\end{abstract}

Kata kunci : fermentasi, nata de pina, Acetobacter xylinum, urea, jenis gula

\section{PENDAHULUAN}

Indonesia memiliki beranekaragam makanan, mulai dari makanan tradisional hingga makanan modern yang pembuatannya sudah melalui bantuan teknologi. Makanan yang dibuat dengan bantuan teknologi bertujuan untuk meningkatkan kualitas gizi dari makanan tersebut. Cara fermentasi merupakan salah satu teknologi yang digunakan dalam membuat makanan. Salah satu contohnya adalah Nata. Bahan untuk pembuatan nata biasanya adalah buah yang mengandung kadar gula yang cukup tinggi, gula 
tersebut akan dikonversi menjadi nata oleh bakteri Acetobacter xylinum.

Nanas (Ananas comosus) merupakan tanaman buah yang berasal dari Brazil. Selain bisa dikonsumsi secara langsung, buah nanas juga memiliki khasiat sebagai obat tradisional. Buah nanas terdiri atas daging buah, kulit dan hati. Bagian buah nanas yang banyak dimanfaatkan adalah daging buah. Daging buah nanas mempunyai tekstur yang lebih lunak, manis dan banyak mengandung air, sedangkan hati dan kulitnya lebih keras dan kurang manis.

Nata berasal dari bahasa Spanyol "natare" yang berarti terapung-apung. Nata termasuk dalam produk fermentasi. Nata dibentuk oleh bakteri asam asetat pada permukaan cairan (medium) yang mengandung gula / sari buah/ ekstrak tanaman lainnya. Pengolahan nanas di Indonesia yang dibilang masih tradisional dan memiliki nilai jual yang rendah menyebabkan diolah menjadi nata lebih menguntungkan. Produk nata yang berasal dai nanas dikenal dengan Nata de Pina.

Nata dibentuk oleh spesies bakteri asam asetat pada permukaan cairan yang mengandung gula, sari buah, atau ekstrak tanaman lain. ${ }^{1}$ Beberapa spesies yang termasuk bakteri asam asetat dapat membentuk selulosa, namun selama ini yang paling banyak dipelajari adalah A. xylinum. Bakteri Acetobacter xylinum, jika ditumbuhkan di media cair yang mengandung gula, bakteri ini akan menghasilkan asam asetat dan lapisan putih yang terapung-apung di permukaan media cair tersebut. Lapisan putih itulah yang dikenal sebagai nata. ${ }^{2}$ Keistimewaan produk ini terutama karena nilai kalorinya rendah. Kandungan terbesar adalah air (98\%), maka produk ini dipakai sebagai sumber makanan rendah kalori. Kenampakan nata adalah seperti sel, warna putih hingga abu-abu muda, aroma asam, rasa tawar atau agak manis, tembus pandang dan teksturnya kenyal. Dalam keadaan dingin, nata agak berserat dan agak rapuh pada saat panas.

Starter nata adalah Acetobacter xylinum. Penggunaan starter merupakan syarat yang sangat penting, yang bertujuan untuk memperbanyak jumlah bakteri Acetobacter xylinum yang menghasilkan enzim pembentuk nata. Bakteri Acetobacter xylinum tergolong family Pseudomonas dan genus Acetobacter. Berbentuk bulat dengan panjang 2 mikron, biasanya terdapat sebagai sel tunggal atau kadang kadang berikatan dengan sel lain membentuk ikatan seperti rantai.Pembentukan nata memerlukan starter sebanyak $10-20 \%$ dari volume media sebagai starter mikroba. ${ }^{3}$

Menurut Thiman (1962) pembentukan nata terjadi karena proses pengambilan glukosa dari larutan gula dalam bahan dasar nata oleh sel-sel Acetobacter xylinum. Kemudian glukosa tersebut digabungkan dengan asam lemak membentuk precursor (penciri nata) pada membrane sel. Prekursorini selanjutnya dikeluarkan dalam bentuk akskresi dan bersama enzim mempolimerisasikan glukosa menjadi sellulosa material diluar sel. Komponen ini akan membentuk sel mikrofibril yang panjang dalam cairan fermentasi.

\section{METODE}

Bahan-bahan yang digunakan dalam percobaan ini adalah sari buah nanas $500 \mathrm{ml}$, gula pasir 10 gr, gula Tropicana slim 10 gr, cuka biang 5 $\mathrm{ml}$, dan bibit Acetobacter xylinum. yang dimasukkan dalam wadah gelas plastik berdiameter $5 \mathrm{~cm}$ dan tinggi $4 \mathrm{~cm}$ sebagai tempat fermentasi, starter nata yaitu Acetobacter xylinum sebanyak 20\% volume medium. Sumber nitrogen yang digunakan yaitu urea sebanyak 3 gram.. Alat-alat yang digunakan dalam percobaan adalah panci, sendok sayur, blender, sendok makan, kain saring, kompor, baskom plastik, ,karet gelang, dan kertas koran.

Pembentukan nata dengan proses fermentasi diawali dengan penghancuran buah nanas madu menggunakan blender lalu disaring dan diambil sarinya. Lalu ditambahkan urea dan gula sesuai variable kemudian dididihkan. Setelah 10 menit didinginkan sampel ditempatkan di dalam wadah plastic dan ditambahkan ditambah cuka sebanyak 5 $\mathrm{ml}$ setelah medium sudah dingin ditambahkan bakteri Acetobacter xylinum ke dalam nampan sebanyak $20 \%$ volume medium lalu tutup rapat dengan kertas koran dan didiamkan pada suhu ruangan selama 14 hari.

Proses pemanenan dilakukan dengan merendam hasil fermentasi selama 3 hari dengan air untuk menghilangkan asam dengan air diganti secara berkala. Kemudian sampel di analisa untuk diuji ketebalan dan dan uji proksimat terhadap variable yang telah ditentukan.

\section{HASIL}

Tabel 1. Hasil percobaan

\begin{tabular}{ccccccc}
\hline & \multirow{2}{*}{ No. } & \multicolumn{5}{c}{ Tebalar dalam 100\% Bahan Kering } \\
\cline { 3 - 7 } & $(\mathrm{mm})$ & $\begin{array}{c}\text { Kadar } \\
\text { air }\end{array}$ & $\begin{array}{c}\text { Kadar } \\
\text { abu }\end{array}$ & SK & LK & PK \\
\hline 1 & 10,2 & 5,04 & 0,75 & 2,29 & 1,12 & 10,88 \\
2 & 11,3 & 5,16 & 0,76 & 2,48 & 1,32 & 11,1 \\
3 & 8,1 & 4,2 & 0,6 & 2,02 & 0,97 & 9,2 \\
4 & 9,8 & 4,1 & 0,62 & 2,12 & 1,13 & 9,89 \\
\hline
\end{tabular}

Keterangan : 1. Tropicana slim; 2 . Tropicana slim + Urea;

3. Gula Pasir; 4. Gula Pasir + Urea

Pada percobaan yang kami lakukan yaitu variable 1 dan 3 menggunakan jenis gula yang berbeda yaitu gula pasir dan Tropicana slim. Nata yang terbentuk menggunakan gula Tropicana slim yaitu variabel 1 lebih tebal yaitu 10,2 mm dari pada 
medium yang menggunakan gula pasir (variabel 3) yaitu $8,1 \mathrm{~mm}$. Selain itu variabel 2 yaitu medium yang ditambahkan urea lebih tebal dari variabel 1 yang tidak ditambahkan urea.

\section{PEMBAHASAN}

\section{Pengaruh penambahan jenis gula terhadap ketebalan nata}

Nata de Pina merupakan bahan pangan hasil fermentasi dari pengolahan air rebusan nanas dengan bantuan Acetobacter xylinum. Bakteri ini bisa hidup pada media rebusan nanas yang mengandung gula, gula akan digunakan sebagai sumber penyedia kebutuhan energi oleh bakteri tersebut. Media rebusan nanas yang mengandung gula digunakan untuk pembentukan felikel nata, dimana dengan adanya kandungan sukrosa didalam gula berfungsi sebagai sumber karbon yang dibutuhkan untuk pertumbuhan bakteri. ${ }^{4}$

Pada percobaan yang kami lakukan yaitu variable 1 dan 3 menggunakan jenis gula yang berbeda yaitu gula pasir dan Tropicana slim. Nata yang terbentuk menggunakan gula Tropicana slim yaitu variabel 1 lebih tebal yaitu 10,2 mm dari pada medium yang menggunakan gula pasir (variabel 3) yaitu $8,1 \mathrm{~mm}$. kandungan karbon yang banyak bisa membentuk nata lebih tebal karena adanya proses polimerisasi oleh Acetobacter xylinum yang mengubah gula menjadi selulosa. Kandungan glukosa dan selulosa memiliki perbedaan gugus $\mathrm{C}$. Glukosa pada gula memiliki 6 gugus $\mathrm{C}\left(\mathrm{C}_{6} \mathrm{H}_{12} \mathrm{O}_{6}\right)$ sedangkan Tropicana slim (sukrosa) memiliki gugus $12 \mathrm{C}$ $\left(\mathrm{C}_{12} \mathrm{H}_{22} \mathrm{O}_{11}\right)$ sehingga nata yang terbentuk pada variabel 1 lebih tebal dari pada variabel $3 .^{5}$

\section{Pengaruh penambahan jenis gula terhadap kadar serat dan protein pada nata}

Nata merupakan hasil olahan pangan secara fermentasi dengan bantuan Acetobacter xylinum, hasil kerja dari bakteri ini menghasilkan suatu lapisan tipis yang terapung diatasnya. Lapisan tipis ini merupakan hasil perubahan suksrosa yang terdapat dalam gula menjadi selulosa secara ekstraseluler sehingga sel - sel bakteri akan terperangkap dalam fiber selulosa. ${ }^{4}$ dan fiber selulosa ini berbentuk partikel yang tebal. Dari hasil uji yang didapat medium yang menggunakan gula Tropicana slim lebih besar kandungan seratnya dari pada yang menggunakan gula pasir peningkatan kandungan serat akan meningkat seiring dengan penambahan gula hingga dicapai kondisi optimum dikarenakan kadar sukrosa yang tinggi merupakan merupakan sumber nutrisi berupa sumber karbon yang dibutuhkan Acetobacter xylinum dalam merubah sebagian glukosa menjadi selulosa.

Ketebalan nata merupakan banyaknya gula (sukrosa) yang dapat diubah menjadi selulosa oleh
Acetobacter xylinum sehingga serat yang terbentuk juga semakin tinggi. Serat kasar yang terbentuk merupakan hasil perombakan gula pada medium fermentasi oleh aktivitas Acetobacter xylinum. ${ }^{6}$ Acetobacter xylinum mengambil glukosa dari larutan gula, kemudian digabungkan dengan asam lemak membentuk prekursor pada membrane sel. Prekursor ini keluar bersama - sama enzim yang mempolimerisasikan glukosa menjadi selulosa diluar sel, jadi dengan adanya penambahan gula (sukrosa) akan meningkatkan jumlah lapisan - lapisan selulosa (serat) yang dihasilkan oleh Acetobacter xylinum. Selulosa yang terbentuk didalam media berupa benang - benang yang bersama dengan polisakarida membentuk jaringan yang terus menebal menjadi lapisan nata.

\section{Pengaruh penambahan urea pada medium pembuatan nata}

Dari hasil penelitian yang kami lakukan didapat bahwa dengan adanya penambahan urea memberikan hasil yang nyata. Hal ini ditunjukan antara variabel 1 dengan variabel 2 , dimana variabel 2 yaitu medium yang ditambahkan urea lebih tebal dari variabel 1 yang tidak ditambahkan urea. Menurut Kornmann faktor nutrisi mempunyai pengaruh yang kuat terhadap sifat, hasil dan komposisi selulosa yang terbentuk. Kecukupan konsentrasi sumber karbon dalam medium dapat merangsang mikroorganisme dalam mensintesa selulosa dan menghasilkan nata dengan ikatan selulosa yang kuat. Kuatnya ikatan selulosa dalam jaringan nata tersebut mengakibatkan serat nata semakin meningkat. Banyaknya serat yang terbentuk akan menentukan tebal nata yang dihasilkan. $^{7}$

\section{Pengaruh Penambahan Urea pada Medium Terhadap Kadar Air pada Nata}

Dari hasil penelitian yang kami lakukan didapat bahwa dengan adanya penambahan urea memberikan hasil yang tidak terlalu signifikan. Pada variabel 2 didapat kadar air yang lebih rendah dari pada variabel 1 yang tidak ditambahkan dengan urea.

Hal ini dapat juga dilihat dari hasil kandungan air yang ada dalam nata de pina pada tabel diatas. pada panambahan urea memberikan jumlah air yang lebih sedikit dibandingkan dengan variabel 1 yang tidak ditambahkan urea. Semakin banyak urea yang ditambahkan selulosa dalam nata semakin kompak sehingga kandungan air semakin sedikit. Bila dibandingkan dengan sampel yang tidak ditambah urea, air yang terkandung didalamnya signifikan lebih besar. Namun jika jumlah urea yang ditambahkan terlalu banyak maka akan menyebabkan nata yang terbentuk menjadi lebih keras. ${ }^{8}$ 


\section{SIMPULAN}

Dari penelitian ini dapat disimpulkan bahwa penambahan gula yang mengandung gugus $\mathrm{C}$ yang besar dapat menghasilkan nata yang lebih baik dari segi ketebalan maupun jumlah serat yang dikandung. Serta dengan adanya penambahan sumber Nitrogen, yaitu urea memberikan hasil nata yang lebih tebal dan lebih baik dari pada yang tidak ditambahkan dengan urea.

\section{DAFTAR PUSTAKA}

1. Lapuz, M. M., Gollardo E.G., \& Palo M.A. The Organism and Culture Requirements, Characteristics and Identity. The Philippine J. Science.98:1967:191 - 109.

2. Sumiyati. Kualitas Nata de Cassava Limbah Cair Tapioka dengan Penambahan Gula Pasir dan Lama Fermentasi yang Berbeda. (Skripsi). Surakarta. Universitas Muhammadiyah.2009

3. Saragih. Membuat Nata de Coco. Jakarta : Puspa Swara.2004

4. Nurhayati. Kajian Pengaruh Kadar Gula dan Lama Fermentasi terhadap Kualitas Nata de Soya, Jurnal Matematika, Sains, dan Teknologi,
7, 40-47. Swissa, M., Aloni, Y., Weinhouse, H. \&Benziman, M. 1980. Intermediary step in Acetobacter xylinum Cellulose Synthesis" Studies whit whole Cells and Cell Free Preparation of the Wild Type and A Celluloses Mutant. J.Bacteriol. 143: 2006: 1142 - 1150.

5. Rizal, H. M., Pandiangan, D. M., Saleh, A., Pengaruh Penambahan Gula, Asam Asetat Dan Waktu Fermentasi Terhadap Kualitas Nata De Corn. Jurnal Teknik Kimia No. 1, Vol. 19, Januari 2013. Palembang.

6. Hidayat, dkk. Mikrobiologi Industri. Yogyakarta: C.V Andi Offset. 2006

7. Kornman, K.S., Wilson, T.G. Fundamentals of Periodontics, 2nd ed, Quitesence Publishing Co Inc, Hong Kong.2003

8. Luwiyanti, H. Pengaruh Penggunaan Sumber Nitrogen pada Medium Filtrat Kulit Buah Pisang Kepok Terhadap Berat, Tebal, dan Sifat Organoleptik Nata. (Skripsi) Semarang : Program S1 Teknologi Hasil Pertanian Fakultas Teknologi Pertanian Universitas Semarang. 2001 